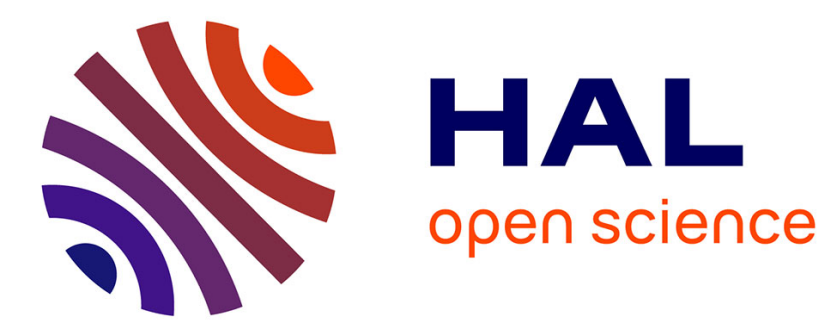

\title{
Vertical digital holographic bench for underexpanded jet gas density reconstruction
}

François Olchewsky, Jean-Michel Desse, David Donjat, Frédéric Champagnat

\section{To cite this version:}

François Olchewsky, Jean-Michel Desse, David Donjat, Frédéric Champagnat. Vertical digital holographic bench for underexpanded jet gas density reconstruction. Digital Holography and 3D Imaging, May 2019, BORDEAUX, France. hal-02196606

\section{HAL Id: hal-02196606 https://hal.science/hal-02196606}

Submitted on 29 Jul 2019

HAL is a multi-disciplinary open access archive for the deposit and dissemination of scientific research documents, whether they are published or not. The documents may come from teaching and research institutions in France or abroad, or from public or private research centers.
L'archive ouverte pluridisciplinaire HAL, est destinée au dépôt et à la diffusion de documents scientifiques de niveau recherche, publiés ou non, émanant des établissements d'enseignement et de recherche français ou étrangers, des laboratoires publics ou privés. 


\title{
Vertical digital holographic bench for underexpanded jet gas density reconstruction
}

\author{
François Olchewsky ${ }^{1}$, Jean-Michel Desse ${ }^{2}$, David Donjat $^{3}$, Frédéric Champagnat $^{4}$ \\ ${ }^{1}$ : ONERA DAAA, 8 rue des Vertugadins, 92190 Meudon, France \\ ${ }^{2}$ : ONERA DAAA, 5 rue des fortifications, 59045 Lille, France \\ ${ }^{3}$ : ONERA DMPE, 2 avenue Edouard Belin, 31400 Toulouse, France \\ ${ }^{4}$ : ONERA DTIS, chemin de la Hunière, 91123 Palaiseau, France \\ Authore-mail address: francois.olchewsky@onera.fr
}

\begin{abstract}
The built of a multi-viewpoint digital holographic bench permits to study snapshots of a three-dimensional underexpanded jet. The coincidence in time between the measurements allows to study unsteadiness of the jet and explain Fluid Dynamics phenomenon.

OCIS codes: (090.0090); (090.1995); (090.2880); (100.3190)
\end{abstract}

\section{Introduction}

In Fluid Dynamics, digital holography permits to reconstruct gas density thanks to tomographical methods. In previous work [1], an horizontal bench has been built in order to reconstruct vertical jets. This bench is composed by 6 Mach-Zehnder interferometer s equi-distributed around the jet to optimize the reconstruction as explained by [2]. As most Fluid Dynamics facilities provide horizontal jets, the multi-viewpoint measurements need to be performed around a vertical circle. This abstract deals with this vertical bench set-up and the first experiment done in one facility outside the lab.

\section{Optical set-up}

This vertical bench is still composed by 6 Mach-Zehnder interferometers equi-distributed around the jet (i.e. there is $30^{\circ}$ between each viewpoint). One of those Mach Zehnder interferometers is shown Fig. 1. To clarify the scheme, the measurement beam is blue while the reference beam is red. The synchronization of the whole viewpoints is given by the $\mathrm{Nd}$ :YAG laser source pulse of $5 \mathrm{~ns}$ and $10 \mathrm{~Hz}$ frequency that is split in 6 to enlighten the 6 interferometers as shown in the scheme Fig. 2. The same principle of blue and red colors is applied. A photograph of the bench is also shown around the facility which is an underexpanded jet with a nozzle of $22 \mathrm{~mm}$ diameter.

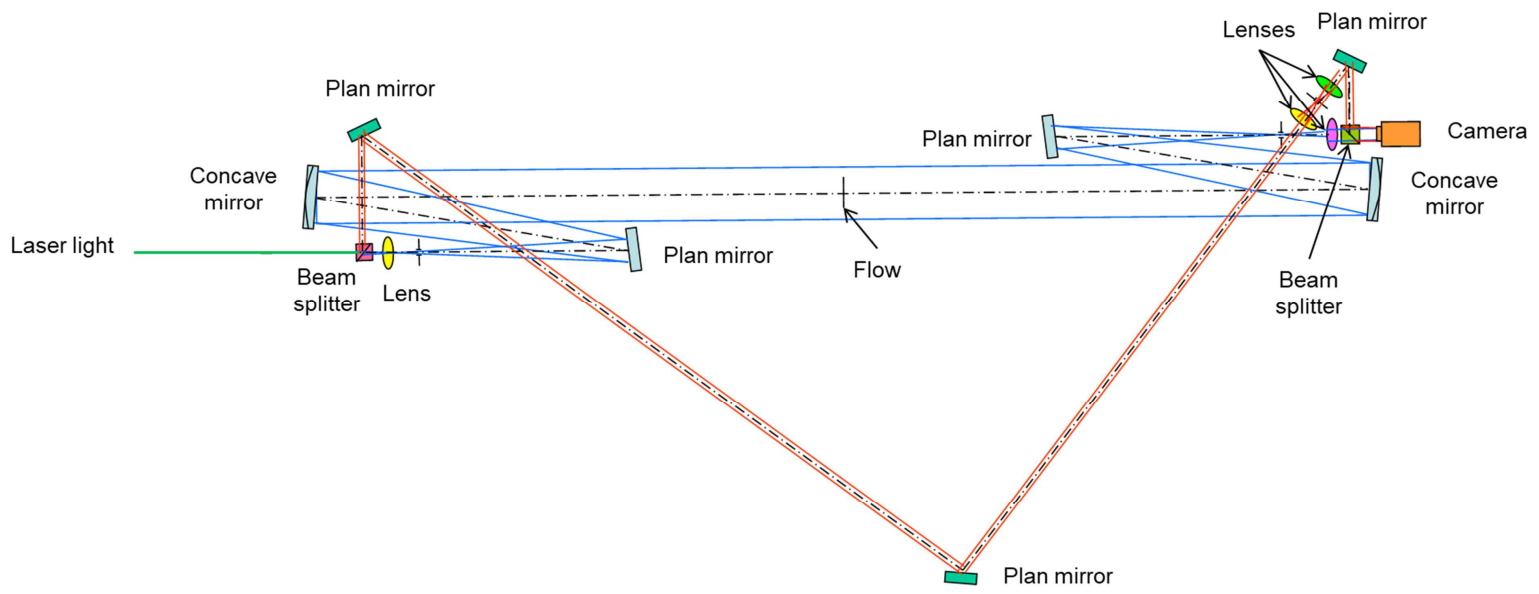

Fig. 1. Scheme of one of the Mach-Zehnder interferometers. 


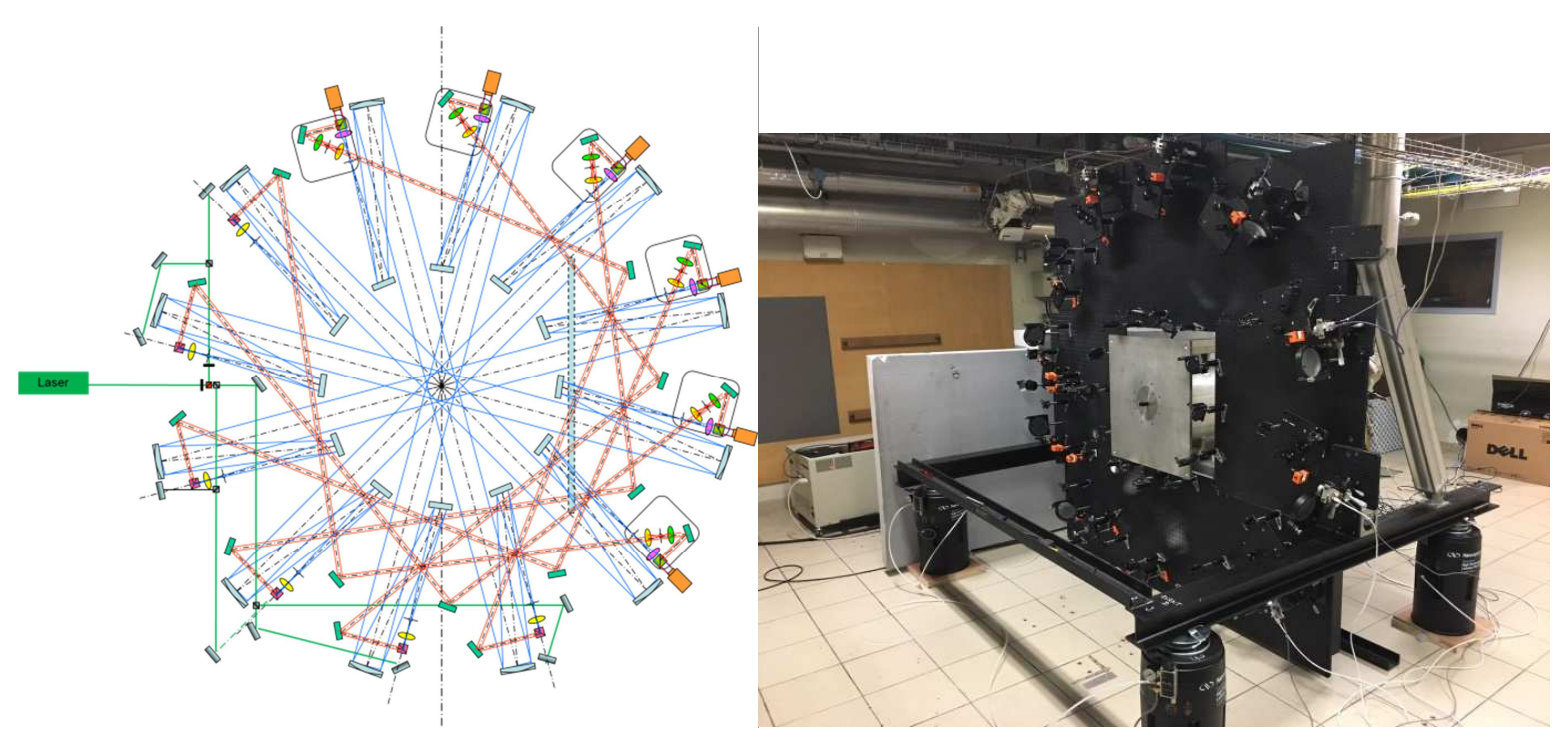

Fig. 2. Scheme and photograph of one of the vertical bench.

\section{Results}

Interferograms are recorded at $10 \mathrm{~Hz}$ for different Nozzle Pressure Ratio (NPR). The tomography based on the minimization of a least squared criterion regularized by Tikhonov by a conjugated gradients method similarly to [3] gives density reconstruction of instantaneous of the jet. The compression structures have a 3 dimensional shape has shown by the iso-densities represented in Fig. 3 for a NPR 3. The simultaneity and short time exposure (5ns) of these measurements permits to understand Fluid dynamics phenomenon while the averaged flow is axisymmetric.

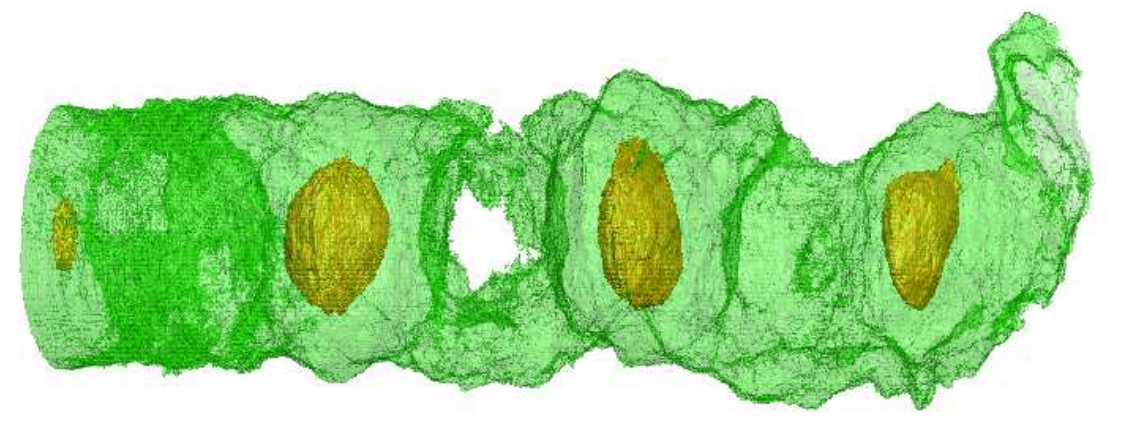

Fig. 3. Reconstructed gas density at NPR3 with two iso-densities of 1,5 and $2,1 \mathrm{~kg} \cdot \mathrm{m}^{-3}$.

\section{References}

[1] F. Olchewsky, Z. Essaïdi, J.-M. Desse and F. Champagnat, "3D reconstructions of jets by multidirectional digital holographic tomography", Proceedings 18th International Symposium on Flow Visualization (2018).

[2] B. Atcheson, I. Ihrke, W. Heidrich, A. Tevs, D. Bradley, M. Magnor, and H.-P. Seidel, "Timeresolved 3d capture of non-stationary gas flows", ACM Trans. Graph 27 (2008).

[3] F. Nicolas, D. Donjat, O. Léon, G. Le Besnerais, F. Champagnat and F. Micheli, "3D reconstruction of a compressible flow by synchronized multi-camera BOS” Exp. Fluids 58 (2017). 